\title{
PRYMAS POLSKI ARCYBISKUP ANTONI KAZIMIERZ OSTROWSKI I JEGO TROSKA O ARCHIDIECEZJE GNIEŹNIEŃSKĄ W CZASIE POBYTU ZA GRANICA (1782-1784) W SWIETLE KORESPONDENCJI Z KAPITULĄ METROPOLITALNĄ W GNIEŹNIE
}

W latach 1777-1784 Kościołowi katolickiemu w Polsce przewodził arcybiskup metropolita gnieźnieński Antoni Kazimierz Ostrowski, prymas Polski. Zanim zasiadł na stolicy gnieźnieńskiej, wcześniej był biskupem inflanckim (17521763) a następnie włocławskim (1763-1777) 1 .

Ocena postaci prymasa Ostrowskiego, pochodzącego z biednej zagonowej szlachty, jest bardzo zróżnicowana. Zasłynął jako znakomity znawca spraw ekonomicznych. W testamencie napisał o sobie, iż w zasadzie był ekonomem. O jego zdolnościach ekonomicznych pisał współczesny mu kanonik kapituły gnieźnieńskiej Baltazar Pstrokoński: „,w ekonomii królem mógł być nazwan i z niej wiele pożytkował". Ten sam pamiętnikarz nisko oceniał jednak jego wykształcenie, podkreślając w nim braki, szczególnie w zakresie prawa kościelnego, teologii i języków obcych: „Mądrym się zdawał, nie będąc nim w gruncie”. Drugi współczesny Ostrowskiemu J. D. Janocki - znając go jeszcze jako biskupa inflanckiego - chwalił w nim żywy i przenikliwy umysł, bystry i głęboki rozum, twierdząc, że chociaż nie posiadał gruntownego wykształcenia, gorliwie starał się posiąść znajomość prawa i tradycji narodowych ${ }^{3}$. Starsza historiografia (J. Korytkowski) wysławiała Ostrowskiego za jego głęboką religijność, praktyki ascetyczne, wzorowe

* Ks. Paweł Staniszewski - dr historii Kościoła, wykładowca w WSD w Łowiczu.

${ }^{1}$ P. Nitecki, Biskupi Kościoła w Polsce. Stownik biograficzny, Warszawa 1992, s. 156; M. Kosman, Między ottarzem a tronem. Poczet prymasów Polski, Poznań 2000, s. 204-205; K. R. Prokop, Sakry metropolitów gnieźnieńskich w XVIII i XIX stuleciu (1681/1688-1915), „Studia Gnesnensia”, 18 (2004) s. 100-101.

${ }^{2}$ Pamiętniki księdza Pstrokońskiego, kanonika katedralnego Gnieźnieńskiego, wyd. E. Raczyński, Wrocław 1844, s. 180.

${ }^{3}$ J. D. A. Janocki, Lexicon derer itztlebenden Gelehrten in Polen, t. 1, Breslau 1755, s. 119: Er hat einen lebhaften und aufgeweckten Geist und einen überaus hurtigen und durchbringenden Verstand. Dabei besitzt er auch ein redliches und großmüthiges Herz. Mit den Schulwissenschaften hat 
życie, dzieła miłosierdzia, przystępność i gościnność4. Współczesny Korytkowskiemu, J. Bartoszewicz chwalił Ostrowskiego za jego gospodarność, usłużność, pracowitość i oszczędność 5 .

Nowsze badania zakwestionowały wzorowe życie kapłańskie prymasa, zwracając uwagę na jego bliższe związki, utrzymywanie fraucymeru w Skierniewicach i Warszawie ${ }^{6}$. Niewątpliwie z kolegium biskupów epoki stanisławowskiej abp Antoni Kazimierz Ostrowski należał do grupy dostojników kościelnych nie zawsze stojących na wysokości zadania, wysługujących się państwom ościennym. Jako senator i mąż stanu orientował się na Rosję, biorąc od niej za usłużność pieniądze. Zamieszany był w sprawę wywiezienia biskupa Kajetana Sołtyka do Rosji. On też przewodniczył komisji opracowującej traktaty rozbiorowe ${ }^{7}$.

Nuncjusz apostolski abp Antonio Eugenio Visconti ${ }^{8}$ w swoim sprawozdaniu do Rzymu z 24 września 1766 roku podsumowującym sytuację panującą w Polsce, w którym scharakteryzował także polski Kościół i jego hierarchię - pisał o biskupie Ostrowskim, iż ,jest bardzo oddany dworowi i wykazuje w tym nawet pewien talent, lecz - oby umiał tak użyć swojej inteligencji dla interesów kościelnych, jak to umie w sprawach gospodarczych" ". Podobną opinię o Ostrowskim podzielał nuncjusz Angelo Maria Durini ${ }^{10}$, który w swojej relacji z 30 września 1767 r. dodał, iż w czasie spotkania Ostrowski robi dobre wrażenie, ale ten pierwszy nie ma do niego zaufania ${ }^{11}$.

er sich nie sehr vermenget. Derer Landes-Gesetze, Rechte und Gewohnheiten hat er sich desto eifriger beflissen.

${ }^{4}$ J. Korytkowski, Prymasi Polski, arcybiskupi gnieźnieńscy i metropolici polscy od roku 1000 aż do dnia dzisiejszego, t. 18, Poznań 2006, s. 110.

${ }^{5}$ Zdolny, pełen życia, nastręczający się każdemu z przysługą, z pomoca, panów sobie ujmował, a do tego zabiegły, gospodarny, rządny, do pracy nie leniwy, ciułał sobie grosz, z którego potem korzystał dla pokazania się pomiędzy ludźmi, i zrobienia sobie stanowiska. Wszystko się Ostrowskiemu udawało, bo też rzadko kto od niego był zręczniejszy. J. Bartoszewicz, Antoni Kazimierz Ostrowski, w: Arcybiskupi gnieźnieńscy, prymasi polscy, Warszawa 1864:.

${ }^{6}$ Kosman, Między ottarzem a tronem, s. 205: Jako prymas żył w Skierniewicach po pańsku, choć bez nadmiernej rozrzutności. Sprawiał wrażenie człowieka nie wywyższającego się ponad drobną szlachtą i szeregowe duchowieństwo, toteż - niezależnie od cytowanych i innych uszczypliwości - na ogół był lubiany. Z wyrozumiałością spoglądano na jego inklinacje ku płci nadobnej skrzydło pałacu warszawskiego zamieszkałe przez jego wybranki nazywano prymasarnią (a był wtedy dobrze po sześćdziesiątce); K. Śmigiel, Słownik biograficzny arcybiskupów gnieźnieńskich i prymasów Polski, Poznań 2002, s. 271-272.

${ }^{7}$ T. Korzon, Wewnętrzne dzieje Polski, t. 1, Kraków-Warszawa 1897, s. 256; Sz. Aszkenazy, Przedmowa, s. VI, w: K. Rudnicki, Biskup Kajetan Soltyk 1715-1788, Kraków-Warszawa 1906.

${ }^{8}$ Abp A.E. Visconti był nuncjuszem apostolskim w Rzeczypospolitej w latach 1760-1767. Zob. H. D. Wojtyska, Acta Nuntiaturae Polonae. De fontibus eorumque investigatione et editionibus. Instructio ad editionem. Nuntiorum series chronologica, t. 1, Roma 1990, s. 314.

${ }^{9}$ A. Theiner, Vetera Monumenta Poloniae et Lithuaniae qentiumque finitimarum historiam illustrantia (dalej: VMPL), Tomi IV, Pars II, Romae 1861, s. 97.

${ }^{10}$ Abp Angelo Maria Durini pełnił urząd nuncjusza w Rzeczypospolitej w latach 1767-1772. Zob. H. D. Wojtyska, Acta Nuntiaturae Polonae, s. 317.

${ }^{11}$ VMPL, s. 225: Sebbene il vescovo di Cujavia abbia fatto una buona figura in questo incontro, 
Kolejny nuncjusz apostolski abp Giuseppe Garampi ${ }^{12}$ pisał o arcybiskupie Ostrowskim do Rzymu w 1774. r. jako o człowieku nieudolnym w rządzeniu diece$\mathrm{zją}^{13}$. Charakteryzując go ubolewał, że Ostrowski nie okazał takiej ruchliwości i zdolności w sprawach Kościoła, jaką odznaczał się we własnych interesach. Według opinii nuncjusza arcybiskup ten dbał gorliwie o własną kieszeń ${ }^{14}$. Czy aby na pewno?

Z wyżej zacytowanych opiniach o osobie prymasa Antoniego Kazimierza Ostrowskiego jako polityka, administratora i biskupa jest wiele prawdy, ale też niemniej wiele przesady. Dla diecezji inflanckiej, włocławskiej a potem archidiecezji gnieźnieńskiej, a więc i dla Kościoła zrobił wiele, może więcej niż cieszący się dobrą opinią u potomnych niektórzy jego poprzednicy czy następcy.

Jedno wydaje się być pewnym, mimo swoich różnych „słabości” oraz kłopotów ze zdrowiem ${ }^{15}$, starał się dbać o archidiecezję gnieźnieńska, w której pasterzował. Nawet w czasie ostatnich dwóch lat swego życia, jakie spędził za granicą (1782-1784) na leczeniu, żywo interesował się sprawami archidiecezji, prowadząc korespondencję z kapitułą gnieźnieńską z której zachowało się jego 17 listó $w^{16}$ przechowywanych $\mathrm{w}$ Archiwum Archidiecezji Gnieźnieńskiej. Pokrótce przyjrzymy się nim, by zweryfikować podane wyżej osądy.

Abp A. K. Ostrowski zanim udał się na leczenie za granicę ${ }^{17}$, dnia 1 czerwca 1782 roku na czas swej nieobecności ustanowił w archidiecezji gnieźnieńskiej administratora $\mathrm{w}$ osobie sufragana łowickiego i kanonika gnieźnieńskiego ks. biskupa Kaspra Szajowskiego ${ }^{18}$.W podróż wyruszył ze Skierniewic 9 czerwca 1782 roku $^{19}$. Należy dodać, iż wyjazdowi prymasa towarzyszyły różne komentarze. Nie tylko thumaczono go powodem zdrowotnym. W majowym wydaniu Poufnych wieści z oświeconej Warszawy można było przeczytać następujący komentarz:

ad ogni modo non lo credo netto; por. M. Loret, Kościół katolicki a Katarzyna II 1772-1784, Warszawa 1910, s. 77.

${ }^{12}$ Abp Giuseppe Garampi był nuncjuszem w Rzeczypospolitej od 20 marca 1772 r. do 16 marca 1776 roku. Zob. H. D. Wojtyska, Acta Nuntiaturae Polonae, s. 319..

${ }^{13}$ Rudnicki, Biskup Kajetan Soltyk, s. 200.

${ }^{14}$ Loret, Kościót katolicki a Katarzyna II, s. 77.

${ }^{15}$ Prawdopodobnie chorował na prostatę. Dowiadujemy się o tym między innymi od jemu współczesnych. T. Ostrowski pod datą 22 stycznia 1782 roku pisał: Ksiaże Prymas powtórnie zapadt na stranquriq (zatrzymanie uryny), ale się już ma lepiej. T. Ostrowski, Poufne wieści z oświeconej Warszawy. Gazetki pisane z roku 1782, Wrocław-Warszawa 1972, s. 50.

${ }^{16}$ Prawdopodobnie listów pisanych przez abpa Ostrowskiego do kapituły było więcej, niestety do dnia dzisiejszego zachowało się tylko 17.

${ }^{17} \mathrm{Na}$ temat wyjazdu abpa Ostrowskiego spekulowała ówczesna prasa. Między innymi wspomniany wyżej T. Ostrowski 14 lutego 1782 roku donosił: Ksiaże Imć Prymas na przyszła wiosnę $w$ myśli poratowania zdrowia swego do Spa wyjechać zamyśla. Bawi się teraz polowaniem; Ostrowski, Poufne wieści, s. 64.

${ }^{18}$ Archiwum Archidiecezjalne w Gnieźnie (AAGn), sygn. ACap. B38, k. 317b; Korytkowski, Prymasi Polski, s. 72.

${ }^{19}$ Prymas wyjechał w tajemnicy, o czym donosił T. Ostrowski: Wyjazd swój ze Skierniewic ukryt Prymas przed catym swoim dworem, tak, że gdy wszyscy byli przy stole, on $w$ droge ruszyt. Ostrowski, Poufne wieści, s. 130. 
„Książe Prymas nie tylko dla zdrowia do wód wyjeżdża, ale żeby się od przyszłego sejmu uchylił, gdzie by się bez przymówek o Biskupa Krakowskiego ${ }^{20}$ nie obeszło. Prze się on, aby miał do tej roboty wchodzić, ale trudno"21. W kilka dni po jego wyjeździe w tym samym czasopiśmie pod datą 13 czerwca 1782 roku pojawił się podobny tekst: „Prymas w przeszłą sobotę ruszył za granicę. Dotąd wyjazd jego nie tylko ma cel polepszenia zdrowia, ale i inne jakoweś ukryte przedsięwzięcia. (...) Mówią nawet, że chociażby Książe przed sejmem kuracją skończył, nie powróci do kraju, ale myśli na jakiś rok we Wrocławiu osiąść, aby i z interesów wyszedł i część dworu pozbył się"22.

Najpierw arcybiskup Ostrowski udał się na kurację do Altwasser na Śląsku (dzisiejszy Wałbrzych) ${ }^{23}$. W podróży zagranicznej towarzyszyli prymasowi dwaj najbliżsi mu kapłani: Melchior Gurowski - proboszcz katedry gnieźnieńskiejej i Jo-

${ }^{20}$ Chodziło o biskupa krakowskiego Kajetana Sołtyka, który zasłynął z tego, że na Sejmie Repninowskim 1767 nie uznał dyktatu ambasadora rosyjskiego Mikołaja Repnina w sprawie równouprawnienia dysydentów, za co wraz z trzema innymi senatorami tj. hetmanem polnym koronnym Wacławem Rzewuskim, jego synem posłem podolskim Sewerynem Rzewuskim oraz biskupem kijowskim Józefem Załuskim 14 października 1767 roku podczas trwania sejmu na rozkaz ambasadora rosyjskiego został uwięziony i wywieziony do Kaługi. Wróciwszy w 1773 r., entuzjastycznie witany przez naród, próbował organizować opór przeciw uznaniu pierwszego rozbioru. Rychło popadł w melancholię, potem obłęd i wdał się w gorące spory z kapitułą krakowską, które zaprzątnęły uwagę Rzeczypospolitej i spowodowały usunięcie go od obowiązków biskupich. Król Stanisław August Poniatowski i Rada Nieustająca na sejmie ubezwłasnowolnili biskupa, ogłaszając, iż postradał on zmysły i osadzili go w pałacu biskupów krakowskich w Kielcach. Zob. Rudnicki, Biskup Kajetan Soltyk, s. $218 \mathrm{nn}$.

${ }^{21}$ Ostrowski, Poufne wieści, Suplement wiadomości de die 16 Maii 1782, s. 116. Abp Ostrowski jako prymas został „wciagnięty” w powyższy spór listami adresowanymi do niego przez obie strony: bpa Sołtyka i kapitułę. Jednak od samego początku nie miał ochoty bardziej angażować się w nią. Zresztą pisała o tym prasa: Ksiqże Prymas martwi się, że do tej roboty wciagnięty. T. Ostrowski, Poufne wieści, s. 82. Wobec tego 23 lutego 1782 roku wyznaczył delegata metropolitalnego w osobie biskupa chełmskiego Macieja Garnysza. Delegat ów otrzymał od prymasa w Skierniewicach instrumentum comissionis, a wraz z nim jednocześnie delegację do wydania ostatecznego w tej sprawie wyroku. Zob. K. Rudnicki, Biskup Kajetan Soltyk, s. 200. Jak się potem okazało, sprawa nie była taką łatwą do zakończenia.

22 Ostrowski, Poufne wieści, Z Warszawy die13 Junii 1782, s. 128. Było publiczną tajemnica, że prymas Ostrowski w Skierniewicach utrzymywał tzw. fraucymer, określany zamiennie prymasarnią. Stąd publicznie mówiono o tym, że wyjechał na dłużej między innymi także i dlatego, aby się na starość pozbył tej asystencji. Tamże, s. 130.

${ }^{23}$ Podobno szukając porady lekarskiej co do stanu swego zdrowia, abp Ostrowski wysłał ks. Januszkiewicza do Wrocławia celem uzyskania porady słynnego tamtejszego doktora de Trallesa, ,jakie mu wody na defekt jego radzi”. Doktor miał odpisać, iż altwaserskie nie mogłyby być dla niego pomocne, ale zachęcił do przyjazdu do Wrocławia, aby tam w gronie innych lekarzy ,determinować miał, które mu wody służyć miały”. Książe Prymas rzeczywiście końcem czerwca odwiedził doktora de Tralles, jednak udał się do Altwasser. Zob. Ostrowski, Poufne wieści, s. 125.

${ }^{24}$ Melchior Gurowski nie cieszył się dobrą opinią. T. Ostrowski tak o nim pisał: x Gurowski Melchior, kanonik - proboszcz gnieźnieński, mający opinię bibosza i lubieżnika. Nieodłączny towarzysz prymasa. Ostrowski, Poufne wieści, s. 255. 
achim Dembowski - archidiakon gnieźnieński ${ }^{25}$. Przebywał tutaj prawdopodobnie do końca września 1782 roku. Jeszcze z początkiem września krążyła po Warszawie wiadomość następującej treści: „Książe Prymas ma zimować w Hamburgu, bo Pragą wzgardził dla swojej subiekcji tam gromadzącej się w tej czasu porze szlachty. Wody mu dotąd nie skutkują. Dał się już słyszeć, że gdy ojczyźnie dla lat podeszłych służyć nie może, może do niej nie powróci. Ale może po sejmie inne rozejdą się wieści osobiście pod pretekstem polowania, o które w Niemczech z tą jak w Polsce wolnością przytrudnej”26. Potem pojawiła się plotka, że „,przezimuje" we Wrocławiu ${ }^{27}$. Jak się później okazało, abp Ostrowski przeniósł się do Frankfurtu nad Menem. W czerwcu 1783 roku za radą lekarzy frankfurckich wyjechał do Spa w Szwajcarii, ale i tutaj nie zaznał ulgi, dlatego wkrótce powrócił do Frankfurtu, gdzie spędził jesień i zimę. Na kilka miesięcy przed swoją śmiercią, opadając już z sił, wiosną 1784 roku abp Ostrowski udał się do Paryża, by szukać porady u najsławniejszych lekarzy francuskich. Gdy i oni nie zdołali mu pomóc, skorzystał jeszcze z porady P. Mesmera, leczącego przy pomocy magnetyzmu zwierzęcego ${ }^{28}$. Chwilowo musiał doznać poprawy, albowiem w liście z dnia 23 lipca tegoż roku do swoich przyjaciół w kraju zapewniał, że wysławszy dwór i rzeczy swoje dwa dni wcześniej, sam za nimi 24 lipca uda się w podróż do Pol$\mathrm{ski}^{29}$. Niestety, nie dane mu to było. Nagle zasłabł i po nadzwyczaj przykładnym przygotowaniu się, prymas Antoni Kazimierz Ostrowski zmarł 26 sierpnia 1784 roku w Paryżu. Stosownie do jego woli, pochowany został w kościele św. Ludwika de Louvre w Paryżu ${ }^{30}$. Natomiast serce prymasa przewieziono do Skierniewic, gdzie 5 listopada 1784 roku w uroczystym pogrzebie, w czasie którego wygłosili mowy pogrzebowe ks. kanonik Grzegorz Zachariasiewicz ${ }^{31}$, późniejszy sufragan łowicki i ks. Wiktor Olszewski ${ }^{32}$, złożono do wspaniałego grobowca, wykonanego jeszcze za jego życia w kościele parafialnym ${ }^{33}$.

${ }^{25}$ Korytkowski, Prymasi Polski, s. 73.

${ }^{26}$ Ostrowski, Poufne wieści, s. 166.

${ }^{27}$ Tamże, s. 171: Z Warszawy 19 września 178,: Książe Imć Prymas we Wrocławiu zimować ma. Zdrowie jego $w$ dawnym stanie.

${ }^{28}$ M. Malinowski, Żywoty arcybiskupów gnieźnieńskich prymasów Korony Polskiej i Wielkiego Księstwa Litewskiego, t. 4, Wilno 1860, s. 195.

${ }^{29}$ Korytkowski, Prymasi Polski, s.102; Śmigiel, Słownik biograficzny, s. 272.

${ }^{30}$ AAGn, ACap. B38, k. 411: „Accepta tristi notitia, ąualiter Celsissimus Princeps Antonius Casimirus de Ostrów Ostrowski, Archiepiscopus Gnesnensis etc. anno Domini millesimo septingentesimo octuagesimo secundo die nona mensis Jurni ex Patria et civitate Skierniewice, Residentia Primatiali, In qua Ecclesiam parochialem de novo splendide erexit et dotavit sepulchrumąue sibi in ea paravit, in exteras Nationes causa curandae infirmae valetudinis diverteret, die vigesima sexta mensis elapsi (Augusti) anno currenti Parisiis vitam temporalem in aeternam Sacramentis munitus commutavit ibiąue in Ecclesia Collegiata S. Ludovici de Louvre sepultus existat, Capitulum decrevit, ąuatenus. etc.".

${ }^{31}$ G. Zachariaszewicz, Kazanie żałobne po wielkiey i drogiey pamięci Mężu Jaśnie Oświeconym Xiażęciu Jmci Antonim Kazimierzu z Ostrowa Ostrowskim (...) przy złożeniu Serca Jego w Kościele Parafialnym w Skierniewicach miane. (...) Roku 1784 dnia 5 Listopada, w Łowiczu w Drukarni Nadworney Prymacyalney.

${ }^{32}$ Korytkowski, Prymasi Polski, s. 104.

${ }^{33}$ Tamże; Śmigiel, Stownik biograficzny, s. 272. 
Od samego początku swego pobytu na obczyźnie abp Ostrowski interesował się sprawami archidiecezji. Wśród licznych trosk prymasa, priorytet wiodły trzy: kwestia wyboru nowego prezydenta Trybunału Koronnego, restauracja katedry gnieźnieńskiej oraz budowa seminarium duchownego w Gnieźnie.

Gdy chodzi o tę pierwsza, przypomnijmy, iż Trybunał Koronny - powołany do życia na sejmie warszawskim w 1578 roku - pełnił funkcję Najwyższego Sądu Krajowego. Instytucję tę utworzono nie dla wszystkich ziem Rzeczpospolitej Obojga Narodów, lecz tylko dla Małopolski, Wielkopolski, Rusi Czerwonej i Podlasia. Wszystkie inne prowincje „sądzić się miały nadal po dawnemu”34.

Obieranie deputatów do Trybunału odbywało się corocznie, gdyż godność ich nie była dożywotnią, jak podkomorzego, sędziego, podsędka i pisarza ziemskiego $^{35}$.W skład Trybunału Koronnego wchodzili deputowani szlacheccy, wybierani corocznie na sejmikach, zwanych deputackimi, w liczbie jednego lub dwóch z każdego województwa. Deputatów szlacheckich było 27, oprócz nich w Trybunale zasiadało 6 deputatów duchownych. Deputatów duchownych wybierały kapituły z kandydatów przedstawionych przez biskupów. Ci ostatni starali się przestawiać tylko takich prałatów i kanoników, na których „mogli liczyć”. Toteż podawali kapitułom do wyboru mężów nie tylko sobie przychylnych, ale poważnych, rozsąanych, biegłych w prawie świeckim i kościelnym, przywiązanych do wiary i Kościoła. Deputaci duchowni brali udział w rozpatrywaniu tych spraw, w których jedną ze stron była osoba duchowna, spraw o dobra należące do Kościoła, a po wygnaniu Arian - także spraw z tzw. „regestru ariańskiego”.

Kapitule metropolitalnej gnieźnieńskiej przysługiwał przywilej dostarczania tymże sądom prezydentów i wiceprezydentów, dlatego też arcybiskupi gnieźnieńscy, począwszy od Jakuba Uchańskiego ${ }^{36}$ aż do księcia Michała Jerzego Poniatowskiego ${ }^{37}$ zabiegali o to, aby te urzędy piastowali ludzie pewni, zdolni i doświadczeni. Nie było przypadku, aby wcześniej przed terminem wyborów, które przeważnie przypadały podczas kapituły generalnej w październiku, tejże kapitule nie mieli przedstawiać odpowiednich kandydatów ${ }^{38}$.

Abp Antoni Kazimierz Ostrowski bardzo dużą wagę przywiązywał do wyboru deputatów na Trybunał Koronny. Trybunaliści występowali nie tylko w imieniu

${ }^{34} \mathrm{~J}$. Korytkowski, Prałaci i kanonicy katedry metropolitalnej gnieźnieńskiej od roku 1000 aż do dni naszych, t. 1, Gniezno 1883, s. 404; Według pierwotnych przepisów konstytucyjnych Trybunał Wielki Koronny miał sądzić od św. Marcina do Wielkanocy w Piotrkowie sprawy z województw wielkopolskich, a od niedzieli przewodniej aż do czasu wyczerpania spraw z województw małopolskich w Lublinie. Na sejmie konwokacyjnym w 1764 roku, dla Wielkopolski zjazdy trybunalskie naznaczono w Piotrkowie i w Poznaniu lub Bydgoszczy, a dla Małopolski w Lublinie i Lwowie. Zmiana ta trwała jednakże tylko jedenaście lat, po czym znów dawny jeden Trybunał przywrócono w roku 1775, który się utrzymał aż do roku 1794. Tamże, s. 415, 418. Por. S. Chodyński, Trybunaliści z Kapituły Włocławskiej, Włocławek 1911, s. 7.

${ }^{35}$ A. Pawiński, Rzady sejmikowe w Polsce 1572-1795 na tle stosunków województw kujawskich, Warszawa 1978, s. 399.

${ }^{36}$ Abp Jakub Uchański piastował godność Prymasa Polski w latach 1562-1581.

${ }^{37}$ Abp Michał Jerzy Poniatowski był Prymasem Polski w latach 1785-1794.

${ }^{38}$ Korytkowski, Prałaci i kanonicy, t. I, s. 405. 
kapituły, ale przede wszystkim biskupa a także ogólnego dobra diecezji. Dlatego deputaci duchowni zasiadając w Trybunale dla sądzenia spraw, jednocześnie mieli za zadanie „pilnowania tam interesów kościelnych”39.

Przeglądając korespondencję prymasa Ostrowskiego z kapitułą metropolitalną $\mathrm{z}$ okresu jego pasterzowania $\mathrm{w}$ archidiecezji gnieźnieńskiej, wielokrotnie napotykamy na przypomnienia, prośby czy nawet monity, by kanonicy w przepisanym prawem czasie dokonali wyboru deputató ${ }^{40}$. Pamiętał o tym będąc także na obczyźnie. Dlatego wkrótce po swoim wyjeździe za granicę, abp Ostrowski w liście do kapituły metropolitalnej datowanym dnia 29 lipca 1782 roku w Altwasser wyrażał zadowolenie z powodu wyboru kanonika Józefa Korytkowskiego ${ }^{41}$ na prezydenta Trybunału. Czytamy w nim: „Po niedoszłej przez dwa roki wciąż po sobie idącej funkcji prezydenckiej z grona WWWM Panów odbieram od Nich uwiadomienie o prawnym wybraniu na prezydenta J X. kanonika Korytkowskiego, zacnego ich konfratra, a tym samym o uprzątniętych przeszkodach, które w niedługim czasie po trzykroć struły nieszczęśliwie podobną elekcję z wielkim pokrzywdzeniem prerogatywy WMWM Panów i z niemałym zawodem interesów Kościoła i ojczyzny. Domyślić się zatem może, z jaką radością i rozweseleniem ducha wyczytałem z ostatniej Ich odezwy tak pocieszającą nowinę $i$ jak szczerym sercem przychodzi mi powinszować WMWM Panom tej prawdziwej i ogólność zgromadzenia Ich interesującej pomyślności”42.

Z powyższych słów wyraźnie widać, jaką wagę abp Ostrowski przywiązywał do kwestii wyboru spośród kapituły metropolitalnej prezydentów Trybunału Koronnego. Nie była to jednak rzeczłatwa utrzymywać na sądach trybunalskich w Piotrkowie i Lublinie przez cały rok delegatów kapitulnych, bowiem wiązały się z tym - oprócz mozolnej pracy - wielkie koszty dalekich podróży i odpowiedniego występowania w tych dwóch siedzibach trybunalskich. Z tego powodu każdy z prałatów i kanoników, jak mógł, dyspensował się od zaszczytu sędziostwa, a wielokrotnie wybierani delegaci, nie mając funduszów na te wielkie wydatki, wzbraniali się od podjęcia swej funkcji ${ }^{43}$. Nie dziwi więc treść powyższego listu, z któ-

${ }^{39}$ Chodyński, Trybunaliści, s. 6.

${ }^{40}$ Zob. AAGn, sygn. Listy, nr 2690 (z dn. 28 VI 1779 r.), nr 2702 (z dn. 18 VI 1780 r.), nr 2928 (z dn. 11 VII 1781).

${ }^{41}$ Ks. Józef Korytkowski prócz kanonii gnieźnieńskiej, posiadał także poznańską. Nie była to jego pierwsza nominacja na ten urząd, bowiem kilka lat wcześniej, tj. w 1777 roku wyznaczony przez abpa Ostrowskiego, wybrany został przez kapitułę na prezydenta Trybunału Koronnego. Wkrótce jednak po jego przybyciu do Piotrkowa, z przyczyn bliżej nie wyjaśnionych Trybunał ten został przerwany i Korytkowski musiał powrócić do Gniezna. J. Korytkowski, Prałaci i kanonicy katedry metropolitalnej gnieźnieńskiej od roku 1000 aż do dni naszych, t. 2, Gniezno 1883, s. 297298.

${ }^{42}$ AAGn, sygn. Listy, Nr 2721.

${ }^{43}$ Ażeby mieć rozeznanie, na jakie koszty wystawiony był np. wiceprezydent Trybunału Koronnego, zacytujmy fragment pamiętnika ks. Balcera Pstrokońskiego, który w latach 1765 i 1766 pełnił tę funkcję. „Obchodziłem się, jakem mógł, ochronnie, ale to też mieliśmy marszałka trybunału najludniejszego i najwspanialszego. Jednakże i mój stolik nie odbywał się co dzień bez kilku osób. Ludźmi też nie zaprzątałem się; dosyć mi było do potrzeby i wygody jeden ksiądz, jeden asystent, dwóch lokaji, jeden hajduk, jeden kucharz i dwóch stangretów. U pacjenta, pana znacznego, raz 
rego dowiadujemy się, iż przez dwa ostatnie lata miał miejsce vacat na tymże stanowisku.

Po kilku miesiącach nie przynoszącej spodziewanego skutku kuracji, we wrześniu 1782 roku abp Ostrowski opuścił Altwasser udając się do Frankfurtu nad Menem, by u tamtejszych lekarzy szukać rady i pomocy. Także stąd cały czas prowadził korespondencję z kapitułą katedralną w Gnieźnie, która dalej ukazuje, jak żywo zajmował się sprawami swojej archidiecezji, także personalnymi. W liście kierowanym do kapituły w dniu 17 września 1782 roku prymas prosił gremium prałatów i kanoników gnieźnieńskich, by kolegialnie wyrazili zgodę na przybranie przez kanonika Jana Kalksteina ${ }^{44}$ koadiutora $^{45}$ W osobie proboszcza łagowskiego ks. Januszkiewicza ${ }^{46}$.

Kiedy zbliżał się czas Kapituły Generalnej w Gnieźnie, abp Ostrowski dnia 12 kwietnia 1783 roku z Frankfurtu pisał do swoich prałatów i kanoników: „Ani odległość miejsca, ani stan zdrowia nie są sposobne zgasić we mnie przytomną zawsze pamięć już to na istotne obowiązki Pasterstwa mojego, już na względy troskliwe, którymi powoduję się zawsze dla przezacnego Grona JWW. WMWM

tylko na kolacji byłem. Od balów i ansamblów jak od powietrza uciekałem". Pamiętniki księdza Pstrokońskiego kanonika katedralnego Gnieźnieńskiego, Wrocław 1844, s. 39-40. Dodać należy, że ks. Pstrokoński, posiadał dochody z trzech kanonii: kaliskiej, metropolitalnej gnieźnieńskiej i św. Jerzego w Gnieźnie oraz pensję wizeprezydencką. Ponadto jako wiceprezydent otrzymał także znaczną sumę pieniędzy od prymasa W. Łubieńskiego. Skoro więc uchodzący za jednego najskromniejszych i najwstrzemięźliwszych deputatów Pstrokoński ponosił takie koszty związane z pełnieniem funkcji wiceprezydenta Trybunału, to co dopiero powiedzieć o prezydencie, który musiał według ówczesnego zwyczaju reprezentować godnie swoje stanowisko, wydawać bale, stypy nie tylko dla członków trybunału i całej palestry, ale i dla przesiadujących w Piotrkowie i Lublinie magnatów i prałatów pilnujących swoich praw. Toteż niektórzy prezydenci niekiedy nie tylko tracili swoje fortuny, ale i popadali w wielkie długi. Zob. Korytkowski, Prałaci i kanonicy, t. 1, s. 412. Nie dziwi więc, że w niektórych latach na urzędzie prezydenta czy wiceprezydenta Trybunału Koronnego był vacat, bowiem brakowało chętnego do piastowania tych urzędów.

${ }^{44}$ Ks. Jan Kalkstein jako kanonik posiadał w kapitule opinię człowieka prawego, roztropnego, wywiązującego się zawsze ,chlubnie” z pełnionych posług i funkcji. Między innymi kapituła delegowała go w roku 1755 na Trybunał Koronny do Piotrkowa i Lublina, na którym z wielką oględnością i zręcznością sprawował urząd wiceprezydenta. Poza tym przez 26 lat pełnił funkcję kaznodziei katedralnego. Korytkowski, Prałaci i kanonicy, t. 2, s. 224.

${ }^{45}$ Pełny tytuł koadiutora brzmiał: pomocnik z prawem następstwa, po łacinie: coadiutor cum iure successionis. W całym Kościele w XVI-XVIII wieku był to dość rozpowszechniony system przy nadawaniu kanonii i biskupstw, zbliżony do zasad elekcji króla vivente rege. Główny posiadacz beneficjum chciał je przekazać osobie bliskiej, najczęściej komuś z rodziny. Zgodę na tego rodzaju akt musieli wyrazić wszyscy, którzy z mocy prawa dysponowali danym beneficjum, a więc kapituła i Stolica apostolska. Z duchownym na koadiutora główny beneficjant spisywał swego rodzaju kontrakt, w którym określone były obowiązki i zasady wynagradzania. Po śmierci lub rezygnacji głównego beneficjanta koadiutor automatycznie wchodził w jego miejsce. Zob. I. Makarczyk, Tomasz Ujejski (1612-1689) biskup kijowski, prepozyt warmiński, jezuita, Olsztyn 2005, s. 27.

${ }^{46}$ AAGn., sygn. Listy, nr 2722. Prawdopodobnie Kapituła nie zaakceptowała tej kandydatury. Dopiero w roku 1786 udało się kan. Kalksteinowi uzyskać dla siebie koadiutora w osobie uczonego Jana Albertrandego, ówczesnego kanonika koadiutora kolegiaty warszawskiej i sekretarza królewskiego. AAGn, ACap. B75, k. 210.; Korytkowski, Prałaci i kanonicy, t. 2, s. 225. 
Panów ze wszech miar najpierwszą u mnie uwagę znajdujących"47. Ze słów tych tchnęła troska o archidiecezję oraz świadomość ciążącej na nim odpowiedzialności za piastowaną godność arcybiskupa. W dalszej części swego listu ujawnił swoją troskę o ponowny wybór deputatów do Trybunału Koronnego: „Nie od rzeczy też być sądzę przypomnieć JWW WM Panom, żebyście się wcześniej między sobą względem przyszłej elekcji prezydenta porozumieli, zawały do niej, jeżeli są jakie, skutecznie uprzątnęli i mnie o osobie czyli osobach tej publicznej usłudze poświęcić się chcących dali wiedzieć"48. Jak bardzo przywiązywał prymas Ostrowski wagę do wyborów prezydenta Trybunału, świadczy fakt, że w dwa miesiące później (być może były kłopoty z jego wyborem w czasie kapituły), przebywając w Spa wystosował 19 czerwca 1783 roku do kapituły kolejny list, w którym zalecał kandydatów na ten urząd: „Następującą Elekcją przyszłego prezydenta Trybunału poprzedzamy naszą do JWW. WM Panów odezwą podając do tej znakomitej funkcji za kandydatów Ichmć Księży Kanoników Stefana Łubieńskiego ${ }^{49}$ Opata Kommendatariusza Trzemeszyńskiego i Baltazara Pstrokońskiego. Spodziewamy się zaś, że nie zachodzi żadna z prawa przeszkoda, która by tą razą zagrozić miała drogę do tej Reprezentacji JWW. WM Panów na czele najpierwszego w kraju Sprawiedliwości S. Namiestnictwa" 50 .

W następnym roku abp Ostrowski zaproponował kandydowanie na urząd prezydenta kanonikowi Danielowi Walewskiemu ${ }^{51}$. Ponieważ długi czas nie otrzymywał od niego odpowiedzi, dlatego - tym razem już przebywając w Paryżu skierował 14 czerwca 1784 roku na ręce kanonika Józefa Ryczywolskiego ${ }^{52}$ list, prosząc o ustalenie kandydata na prezydenta Trybunału. Informując o podjętych wcześniej krokach w tej sprawie pisał w nim: „I sam mocny list pisałem i wdałem przyjaciół moich do Imć X Kanonika Wawelskiego, żeby się na ten rok podjął Prezydencji i nie mam jeszcze od niego rezolucji, i jeżeli się nie doczekam, będę przymuszony posłać na ręce WM Pana Blankiet in Ordine zapisania na nim kandydatów do elekcji, w tymczasem na wszelki przypadek niech Imć Capitulares

${ }^{47}$ AAGn, sygn. Listy, nr 2728.

${ }^{48}$ Tamże.

${ }^{49}$ Stefan Łubieński był krewnym prymasów Macieja i Władysława, synowcem ostatniego. W 1760 roku został kanonikiem gnieźnieńskim. W roku 1764 wybrany na wiceprezydenta Trybunału prowincji wielkopolskiej. W 1790 roku prekonizowały na biskupa sufragana gnieźnieńskiego. Zmarł w Gnieźnie 2 maja 1808 roku. Zob. Korytkowski: Prałaci i kanonicy, t. 2, Gniezno 1883, s. 547-548.

${ }^{50}$ AAGn, sygn. Listy, nr 2730. Prezydentem piotrkowskim został wówczas wybrany kanonik Stefan Łubieński. Zob. Korytkowski, Prałaci i kanonicy, t. 1, s. 409.

${ }^{51} \mathrm{~W}$ momencie otrzymania propozycji Daniel Walewski był archidiakonem gnieźnieńskim, koadiutorem kanonii gnieźnieńskiej. W 1814 roku został kantorem gnieźnieńskim. Posiadał także inne godności: m.in. od 1793 roku był kanonikiem kantorem krakowskim. Zob. J. Korytkowski, Prataci i kanonicy katedry metropolitalnej gnieźnieńskiej od roku 1000 aż do dni naszych, t. 1, Gniezno 1883, t. 4, Gniezno 1883, s. 202-203.

${ }^{52}$ Ks. kanonik Józef Ryczywolski był zasłużonym sekretarzem i prokuratorem kapituły metropolitalnej gnieźnieńskiej. W latach 1767-1788 pełnił funkcję ,,prefekta fabryki” przy prowadzeniu restauracji archikatedry gnieźnieńskiej. Zob. J. Korytkowski, Prałaci i kanonicy katedry metropolitalnej gnieźnieńskiej od roku 1000 aż do dni naszych, t. 3, Gniezno 1883, s. 427-428. 
wcześnie się między sobą miarkują, kogo by wysadzić na ten urząd, jeżeli się nie uda namówić na tę ofiarę Imć. Kanonika Walewskiego"53. W cztery dni później, tj. 18 czerwca 1784 roku ponownie wysłał do kanonika Józefa Ryczywolskiego jeszcze jeden list poświęcony tej sprawie. Zalecał w nim - wobec przeciaggającego się milczenia kanonika Daniela Walewskiego - dalszych dwóch kandydatów na prezydenta: kanonika Maksymiliana Skrzetuskiego ${ }^{54}$ i kanonika Józefa Rokossowskiego ${ }^{55}, \mathrm{z}$ pozostawieniem jednak kapitule swobody wyboru ${ }^{56}$. Prosił więc Ryczywolskiego: „Jak się też ułoży elekcja prezydenta, raczysz mi WM Pan donieść pod dawnym adresem na Frankfurt, bo mnie to, chociaż w kuracji i przy zdrowiu dosyć słabym, naturalnie interesuje. Wszakże w wszelakim stanie, zawsze i wszędzie miło mi ponowić mu jednostajne upewnienie, żem w równych dla niego sentymentach szczery przyjaźni i szacunku prawdziwego" ${ }^{57}$. Jednak cały czas Ostrowski miał nadzieję, iż godność tę otrzyma i przyjmie kanonik Walewski. Według niego, nawet tylko koadiutorstwo tego ostatniego nie stanowiło przeszkody wyboru na prezydenta. Świadczy o tym dopisek na dole listu: „Jeżeliby się jeszcze Imć. X Kan. Walewski namyślił przyjąć na siebie Rezydencję, może być śmiało obranym. Nec obest, że jest dopiero koadiutorem, bo Rada Nieustająca już tę kwestię dla korony affirmaitve rezoliuowała" 58 .

Tego samego dnia, tj. 18 czerwca 1784 roku abp Ostrowski wysłał w tejże sprawie drugi list, bezpośrednio adresowany do kapituły, który pokazuje, ile zabiegów podejmował prymas celem znalezienia odpowiednich kandydatów na urząd prezydenta Trybunału: „Ani stan zdrowia mego, ani znaczna odległość od kraju, nie przeszkodziły mi, chociaż z daleka, zaradzać o przyszłej elekcji Prezydenta. Dadzą mi świadectwo właśnie JWW. WM Panów współbracia, żem od dawnego czasu zapraszał wielu z nich do podjęcia się dobrowolnego tej publicznej usługi. Wszakże, gdy nie znalazłem ochotnika, któryby poświęcić się chciał na tę ofiarę, w tymczasem potrzeba wszelako na dopełnienie Prawa, przystapić do pomienionej elekcji i obrać nowego prezydenta" ${ }^{59}$. Oczywiście w dalszej części

${ }^{53}$ AAGn, sygn. Listy, nr 2734.

${ }^{54}$ Ks. Maksymilian Skrzetuski miał już doświadczenie w tej materii, bowiem w 1776 roku obrany został prezydentem Trybunału Koronnego, któremu - jak pisze Korytkowski - z godnością, chlubą dla siebie i zaszczytem dla kapituły przewodniczył, nie żałując trudów i wielkich nakładów. W nagrodę za tę publiczną służbę król mianował go opatem komenadtoryjnym cystersów w Wągrowcu. Korytkowski, Prałaci i kanonicy, t. III, s. 523.

${ }^{55}$ Ks. Józef Rokossowski, który oprócz kanonii gnieźnieńskiej posiadał także poznańską - również miał niemałe doświadczenie w reprezentowaniu kapituły metropolitalnej. Między innym w 1776 roku jako jej reprezentant razem z dziekanem Teodorem Siemieńskim uczestniczył w konferencji biskupów i kapituł polskich poświęconej m.in. sprawie rozłożenia na duchowieństwo powiększonego subsidii charitativi. Po wyborze na stolicę prymasowską biskupa kujawskiego Antoniego K. Ostrowskiego, wraz z kanonikiem M. Gurowskim - dostapił od kapituły zaszczytu zaproszenia arcybiskupa nominata na arcybiskupstwo gnieźnieńskie. Z wyboru kapituły metropolitalnej prezydował na Trybunale Koronnym dopiero w 1786 roku. Korytkowski, Prałaci i kanonicy, t. 3, s. 380.

${ }^{56}$ AAGn, sygn. Listy, nr 2735.

${ }^{57}$ Tamże.

${ }^{58}$ Tamże.

${ }^{59}$ AAGn, sygn. Listy, nr 2736. 
przedłożył gremium kapitulnemu kandydatury dwóch powyższych kanoników: Skrzetuskiego i Rokossowskiego.

Trzy dni później, tj. 21 czerwca 1784 roku abp Ostrowski wysłał do kapituły jeszcze jeden list poświęcony powyższej sprawie. Jak się później okazało, był to ostatni - zachowany - list napisany przez prymasa do swoich prałatów i kanoników gnieźnieńskich. Uczynił to w obawie nie dostarczenia do adresata poprzedniego listu: „Nie ufając drodze pocztowej nie zawsze wiernie składy sobie powierzone na swoje miejsce dostawiającej, rozumiem tym sposobem zaspokoić troskliwość moją gdy uczyniwszy do JWW. WM Panów odezwę dnia onegdajszego, to jest 18 tego miesiąca, znowu Im ślę dziś tę powtórną wyrazy pierwszej wypisująca $^{60}$. Tak jak w poprzednim liście, najpierw ubolewał oraz niejako wypominał swoim kapłanom: Czyniłem przed czasem przyzwoite kroki do niektórych Zgromadzenia JWW. WM Panów zacnych członków, zapraszając ich i zagrzewając miłością dobrego obywatelstwa, żeby następującą funkcję prezydencką przyjąć na siebie nie odmówili. Ale gdy nigdzie nie znalazłem dobrej woli i ochoty, a tymczasem zbliżony termin elekcji tego sędziego nie zostawuję więcej wolności do dłuższych namysłów, muszę więc zamknąć się ściśle w obrębach obowiązków moich i podać, jak czynię za kandydatów do pomienionej funkcji prezydenckiej Imć Xięży kanoników Skrzetuskiego i Rokossowskiego"61. Oczywiście prymas potwierdził pozostawienie kapitule wolności wyboru. Jak się później okazało, ostatecznie kanonik D. Walewski przyjął propozycję, o czym informuje J. Korytkowski: „W roku 1783 i 1784 prezydował jako delegat kapituły metropolitalnej z chlubą na trybunale koronnym, wskutek czego ozdobiony został przez króla Stanisława Augusta orderem św. Stanisława" 62 .

$\mathrm{Z}$ powyższych przykładów może dziwić, a nawet i denerwować swoista „natarczywość" prymasa Ostrowskiego w kwestii wyboru z grona kapituły metropolitalnej prezydenta do Trybunału Koronnego. Trzeba jednak go zrozumieć i dostrzec rolę, jaką spełniała ta funkcja dla Kościoła. Prezydenci lub ich zastępcy mogli na posiedzeniach Trybunału Koronnego wyjednać dla danej diecezji czy kapituły bardzo ważne uprawnienia czy zwolnienia. Za przykład może posłużyć wspomniany wyżej kanonik Daniel Wawelski, którego zasługi wychwala J. Korytkowski ${ }^{63}$.

W czasie pobytu arcybiskupa Ostrowskiego za granica, z jego polecenia, przeprowadzana była wizytacja generalna całej archidiecezji gnieźnieńskiej. Wizytację tę prymas zapowiedział już w roku 1777. Przeprowadzona była w latach 1778-

\footnotetext{
${ }^{60}$ AAGn, sygn. Listy, nr 2737.

${ }^{61}$ Tamże.

${ }^{62}$ Korytkowski, Prałaci i kanonicy, t. 4, s. 202.

${ }^{63}$ Podczas tej ważnej funkcji, korzystając z pauzy, odbył wśród wielkiego natężenia, bo w bardzo krótkim czasie, w dwóch miejscach o dwanaście mil od siebie odległych, termina graniczne w dobrach arcybiskupich i też dobra od kondemnat szczęśliwie obronił, jak dowodzi list jego do jednego z prałatów gnieźnieńskich pisany. Tak samo troszczył się o dobro kapituły metropolitalnej podczas pobytu na trybunale lubelskim w roku 1785, przypominając jej o przypadającej kondenscesji granicznej z chorążym wieluńskim w kluczu dóbr jej Kamionka i prosząc, aby wyznaczonego terminu dopilnowała. Korytkowski, Prałaci i kanonicy, t. 4, s. 202-203.
} 
1783. Prymas osobiście dokonał wizytacji generalnej archikatedry gnieźnieńskiej w 1779 roku. Resztę archidiecezji wizytowali delegowani przez niego kanonicy kapituły metropolitalnej. On od samego początku czuwał, żeby przeprowadzono ją sumiennie. Cele wizytacji były następujące: utrzymanie karności duchowieństwa, odnowa moralna świeckich i utrzymanie własności kościelnej ${ }^{64}$.

Abp Ostrowski interesował się przebiegiem wizytacji generalnej także przebywając za granica, czego wyraz dał w liście z dnia 8 października 1782 roku: „Chociaż oddalony na czas od miłego widoku Ojczyzny mojej i tej ukochanej Oblubienicy, której przez najświętsze urzędu, i powołania obowiązki winien jestem najtroskliwszą pieczołowitość, czuję jednak słodką w gruncie duszy mojej pociechę z odgłosu, jaki mnie tu dochodzi, już to o wzroście fabryki kościoła, już o przychodzącym do zupełnego końca dziele opisów i układów wizyty generalnej. Te są największe powody dzisiejszej do JWM WM Panów odezwy mojej, przez którą umyśliłem oświadczyć im z serca i prawdziwe ukontentowanie moje i pełne uprzejmej przychylności pasterskie błogosławieństwo"65. Prymas miał bowiem nadzieję, że po powrocie będzie mógł przystapić do redakcji końcowego dekretu reformacyjnego dla całej archidiecezji.

Prawdopodobnie prośba ta nie była dostatecznie realizowana, ponieważ w kilka miesięcy później w liście do kapituły metropolitalnej datowanym 12 kwietnia 1783 roku we Frankfurcie nad Menem prymas Ostrowski ponownie nawiązał do sprawy ukończenia wizytacji generalnej, prosząc o przyspieszenie prac nad jej aktami: „Nawzajem spodziewam się, że z strony swojej zalecicie JWW.WM Panowie potrzebne do uzupełnienia wizyty generalnej robót wydziały wyśpieszyć jak najprędzej, i zbór tych tak długo oczekiwany do Archiwum mojego oddać”66. Okazuje się, że także i ten monit nie przyniósł spodziewanego efektu. Prymas więc $\mathrm{w}$ swej cierpliwości postanowił raz jeszcze zwrócić się do gremium prałatów i kanoników gnieźnieńskich z ponownym apelem w tej sprawie. Uczynił to w liście z 4 października tegoż samego roku. Donosił w nim, iż planuje jesienią następnego, tj. 1784 roku powrót do Gniezna. Dlatego też prosił, by na ten czas uporządkowane zostało archiwum i wykonanie postanowień wizytacji generalnej: „Alboż przynajmniej na owy czas zastanę Archiwum zupełnie i należycie ułożone a wszystkie inne funkcje stosownie do przepisów Wizyty Generalnej tak dokładnie uskutecznione, żebym przecie na koniec za życia mego do Dekretu Reformacyjnego przystapić mógł. Co wszystko jeszcze i teraz przypominam JWW.WM Panom (...) polecam najusilniej pełen nadziei, że przeciwnym doświadczeniem duch mój nie będzie zasmucony"67. Jak się potem okazało, niestety nie dane mu było cieszyć się „przystapieniem do dekretu reformacyjnego".

Przez cały czas pobytu prymasa Ostrowskiego za granicą trwała restauracja katedry gnieźnieńskiej. W swojej korespondencji z kapitułą arcybiskup bardzo żywo interesował się tą sprawą prosząc, by go na bieżąco informowano o przebiegu prac renowacyjnych. To była - oprócz wizytacji generalnej i spawy wyboru

${ }^{64}$ Śmigiel, Stownik biograficzny, s. 269.

${ }^{65}$ AAGn, sygn. Listy, nr 2723.

${ }^{66}$ AAGn, sygn. Listy, nr 2728.

${ }^{67}$ AAGn, sygn. Listy, nr 2731. 
deputatów do Trybunału Koronnego - kolejna troska Ostrowskiego, dla której poświęcił wiele sił i energii.

W tym miejscu wypada przypomnieć, iż w 1760 r. Gniezno dotknęła katastrofa pożaru. Dachy i hełmy wież katedry spaliły się całkowicie, runęło sklepienie w prezbiterium, niszcząc wielki ołtarz, częściowo stalle i posadzkę. Sklepienie nad nawą główną, nadwątlone ogniem, groziło zawaleniem, dachy kaplic były uszkodzone ${ }^{68}$. Przed prymasem i kapitułą stanęło poważne zadanie zabezpieczenia i odbudowy katedry. Historia tej odbudowy, trwającej z przerwami blisko 30 lat (1760-1790), jest dobrze znana, tak dzięki takim przekazom współczesnym, jak nieoceniony Pamiętnik reparacyi kościoła metropolitalnego pisany przez kanonika Balcera Pstrokońskiego ${ }^{69}$, oraz rachunki fabryki kościoła z lat 1767-1782 - jak i dzięki badaniom Stanisława Lorentza, poświęconym temu okresowi dziejów katedry ${ }^{71}$.

Prace nad restauracją i nowym wyposażeniem katedry przebiegały w dwóch fazach: pierwszej, w latach 1760-1767, za rządów prymasa Władysława Łubieńskiego $^{72}$, i drugiej, od 1778 r., za czasów prymasa Antoniego Ostrowskiego ${ }^{73}$. $\mathrm{W}$ okresie pasterzowania tego drugiego pracami renowacyjnymi przy katedrze metropolitalnej kierował kanonik gnieźnieński Józef Ryczywolski, który osobiście przesyłał swojemu arcybiskupowi informacje o podejmowanych działaniach. W listopadzie 1782 roku przesłał prymasowi plany przyozdobienia katedry. W odpowiedzi abp Ostrowski w liście datowanym we Frankfurcie dnia 30 listopada tegoż roku pisał do niego: „Z całego opisu fabryki kościoła metropolitalnego widzę, jak doskonale uczyniłeś WM Pan rozporządzenie do zupełnej ozdoby tej bazyliki. Wszystko mi się podoba, wszystko wielce chwalę i aprobuję, co WM Pan ułożyłeś na przyszły rok do kontynuacji tego rozpoczętego dzieła. Pokazywałem całą tę plantę bawiącym tu przy boku moim prałatom i nikt nie znajduje, co by można w niej odmienić lub przydać. Znam WM Pana gorliwość o ozdobę tego Domu Bożego, a wdzięczność moja, która mu za jego pracę i starania jestem winien, chyba wraz z życiem skończyć się może"74. Był jednak jeden problem. Z powyższego tekstu dowiadujemy się, że rozliczne prace budowlane uniemożliwiały autorowi listu finansowanie odbudowy katedry w roku następnym. Powodem tego

${ }^{68}$ H. Kozakiewiczowa, A. Sławska, J. Eckhart, A. Wasilkowska, Sztuka renesansowa i barokowa, w: Dzieje Gniezna, red. J. Topolski, Warszawa 1965, s. 424.

${ }^{69}$ AAGn, ACap. B 112 - B. Pstrokoński, Pamiętnik reparacji kościoła metropolitalnego gnieźnieńskiego po zgorzeniu jego dnia 25 sierpnia R.P. 1760 do roku 1788 kontynuowany. b. p.

${ }^{70} \mathrm{I}$. Walkowski, Wspomnienie o kościele metropolitalnym $w$ Gnieźnie, napisane $w 1865 r$, Gniezno 1876, s. 50.

${ }^{71}$ Kozakiewiczowa, Sławska, Eckhardt, Sztuka renesansowa i barokowa Gniezna, s. 424.

${ }^{72}$ Abp Władysław Aleksander Łubieński piastował godność Prymasa Polski w latach 17591767.

${ }^{73} \mathrm{Za}$ czasów Ostrowskiego prowadzono roboty przy elewacjach zewnętrznych katedry, zbudowano od południa i północy dwie nowe kruchty, przytykające do wież a pod nimi pomieszczenia biblioteczne i Nowy Kapitularz. Zob. Kozakiewiczowa, Sławska, Eckhart, Wasilkowska, Sztuka renesansowa i barokowa, s. 426.

${ }^{74}$ AAGn, sygn. Listy, nr 2724. 
była przebudowa pałacu prymasowskiego w Warszawie ${ }^{75}$, na którą w roku ,przyszłym" miał wyłożyć 300 tysięcy złotych oraz inne inwestycje w archidiecezji, np. rozpoczęta budowa Domu Księży Emerytów w Łowiczu ${ }^{76}$. Ponadto abp Ostrowski posiadał jeszcze jeden priorytet $\mathrm{w}$ swoich planach: budowa seminarium duchownego, która w czasie jego pobytu za granicą była w toku ${ }^{77}$. Prymas chciał ją jak najszybciej ukończyć, o czym pisał w powyższym liście: „Co do Fabryki Seminarij, tę musze podsycić, ażeby na przyszłe lata Koniec swój wzięła"78. Stąd prosił kanonika Ryczywolskiego, aby nie licząc na jego wsparcie finansowe, własnymi siłami prowadził odbudowę katedry: „Ciagnij zatem Kochany Prałacie tę Fabrykę tyle i puty, ile i póki na nią pozostający jeszcze gotowy fundusz wydostarczy, a gdy się ten zupełnie skończy, zalimituj Ją ad feliciora tempora. Wszakże upewniam WM Pana, że byle mi Bóg pozwolił jeszcze jaki rok życia, obmyślę z czasem sposoby, ażeby cała ta planta, której mi WM Pan komunikowałeś, do zupełnego skutku przeprowadzona była" ${ }^{\prime}$.

Przy okazji należy wspomnieć, iż abp Ostrowski bardzo cenił sobie zasługi ks. kanonika Józefa Ryczywolskiego, czego wyraz dał we wcześniejszym liście z 8 października 1782 roku: „Wszakże nie mogę w szczególności pominąć gorliwych prac i nieoszczędnych i ofiar, jakie z grona JWW.WM Panów Mężowie, JWX Sufragan Łowicki W. Imci. X. Kanonik Ryczywolski z miłości dobra kościoła i chwały Boskiej podejmują i gdy ja z osoby mojej (jeżeli mi Bóg pozwoli życia) pragnę Im słusznej wdzięczności mojej okazywać dowody, niemniej też spodzie-

${ }^{75}$ Prymas Ostrowski rozpoczął przebudowę pałacu w 1777 roku. Było to najpoważniejsze wydarzenie architektoniczne w Warszawie końca lat siedemdziesiątych XVIII wieku. Przebudowa trwała 6 lat, o czym świadczy tablica marmurowa umieszczona nad drzwiami przedpokoju. Zob. F. K. Kurowski, Pamiqtki miasta Warszawy, t. 1, Warszawa 1949, s. 67-68; M. Kwiatkowski, Architektura pałacowa i willowa w Warszawie XVIII w., w: Warszawa XVIII wieku, zeszyt 3, red. J. Kowecki, Warszawa 1975, s. 63; Wielka historia Polski, t. 6, Polska w czasach przełomu (1764-1815), red. S. Grodziski, Kraków 1999, s. 86.

${ }^{76}$ Oficjalnej erekcji Domu Księży Emerytów jako osoby prawnej dokonał prymas Ostrowski dnia 31 maja 1782 roku; Zob. AAGn, sygn. ACap. B10, k. 53-98; Budowę domu rozpoczęto w 1782 roku. Z krótkich wzmianek w aktach Domu Księży Emerytów wiadomo, że jego budowa trwała dwa lata. Zob. Archiwum Kapituły Łowickiej w Łowiczu (AKŁ), Akta Domu Księży Emerytów, t. I, dotyczące korespondencji kapituły łowickiej w sprawach emerytów lat 1821-1861, s.181-185; P. Staniszewski, Szpitalnictwo kościelne w archidiakonacie łęczyckim i łowickim do 1795 roku, Warszawa 2004, s. 160.

${ }^{77}$ Prymasowskie Wyższe Seminarium Duchowne w Gnieźnie powołał do życia abp S. Karnkowski w 1602 roku. Według wzmianek pochodzących z 1769 roku, stary gmach seminarium był bardzo zniszczony. Na prowadzenie jakichkolwiek napraw brakowało pieniędzy. Z pomocą przyszedł seminarium abp A. K. Ostrowski, który polecił wybudować nowy gmach. Na ten cel przeznaczył własne fundusze. Nowy budynek wybudowano w latach 1782-1783. Budynek ten stoi do dzisiaj, w którym nadal mieści się seminarium duchowne. Zob. M. Aleksandrowicz, Wychowawcy $i$ wychowankowie seminarium gnieźnieńskiego w latach 1602-1718, „Roczniki Teologiczno-Kanoniczne", 13 (1963) z. 4, s. 111; Cz. Pest, Rektorzy seminarium duchownego w Gnieźnie 1602-1605, Gniezno 2005, s. 25, 36.

${ }^{78}$ AAGn, sygn. Listy, nr 2724.

${ }^{79}$ Tamże. 
wam się, że JWW. WM Panowie zechcecie wspomnianym prałatom oddawać sprawiedliwość i świadczyć przychylne względy swoje ${ }^{80}$ ".

Na początku stycznia 1783 roku prymas otrzymał od kapituły metropolitalnej życzenia noworoczne. Prawdopodobnie, informując swego arcypasterza o przebiegu prac renowacyjnych przy katedrze, prałaci i kanonicy gnieźnieńscy, mimo wcześniejszej deklaracji abpa Ostrowskiego w sprawie odbudowy katedry, prosili go o pomoc finansową przy realizacji tej inwestycji. Niestety odpowiedź abpa gnieźnieńskiego z dnia 11 stycznia 1783 r. nie była po ich myśli, tzn. podobna do tej, jaką wcześniej, tj. w listopadzie 1782 roku przesłał kanonikowi Ryczywolskiemu: „Komunikował mi Imć X Kanonik Ryczywolski, zacny konfrater WMWM Panów całego układu fabryki do dalszego uskutecznienia pozostającej. Nie mam przeciwko temu co mówić, podoba mi się wszystko, szczególniej tylko rad bym, żeby to dzieło z wolna prowadzone było do swego końca, a raczej, żeby w przyszłym roku tyle tylko pociągnęła się w kontynuacji swojej ta robota, ile wystarczy resztujący gotowy fundusz. Gdy bowiem następującego lata przedsięwziąłem nieodmiennie skończyć pałac Warszawski zewnątrz i wewnątrz i już na ten koniec cały mój zbiór, jaki z oszczędności za granicą i z innych źródeł wzróść może, dobrowolnie sakryfikowałem, gdy przy tym Seminarium w Gnieźnie i Szpital „Emeritorum” w Łowiczu wołający na mnie o pomoc i wsparcie, na koniec gdy dotąd wszystkie dochody stołu Prymasowskiego i moje własne na rzecz miejsca, to jest na stawianie nowych świątnic i budynków y na ulepszenie opustoszałych, z gruntu dóbr jedynie obracałem, oczywista zatem rzecz jest, że chcąc w przyszłym roku udzielić się fabryce katedralnej, musiałbym zaciągnąć długów i zostawić po mnie interesa w podobnym, jak zostawił nieboszczyk Xiąże Poprzednik mój zakłóceniu..." ${ }^{\$ 1}$. Powyższy cytat pokazuje, jaką zasadą w sprawach ekonomicznych kierował się prymas Ostrowski: nigdy nic na kredyt. Stąd jest zrozumiałym, iż u współczesnych cieszył się opinią doskonałego administratora i ekonoma. Zalecał więc kontynuowanie prac przy katedrze, tylko w ramach posiadanej gotówki, gdyż inne prace budowlane, szczególnie budowa pałacu prymasowskiego w Warszawie, wyczerpały jego fundusze a chciałby uniknąć zaciagania długu. Jednak cały czas miał w pamięci konieczność wsparcia odbudowy katedry.

W liście pisanym z Frankfurtu przed zbliżającymi się obradami kapituły ${ }^{82}$, dnia 12 kwietnia 1783 roku dał kolejne świadectwo o sobie jako troskliwym i zapobiegliwym pasterzu, podejmując ponownie temat odbudowy katedry gnieź-

${ }^{80}$ AAGn, sygn. Listy, nr 2723; Zob. Korytkowski, Prałaci i kanonicy, t. 1, s. 429 (Autor podaje tutaj błędną sygnaturę Listu nr 2705, dawniej nr 42, z dnia 21 maja 1781 roku zamiast właściwą tj. nr 2723).

${ }^{81}$ AAGn, sygn. Listy, nr 2725.

${ }^{82}$ Stałe kapituły generalne w Gnieźnie od niepamiętnych czasów odbywały się dwa razy do roku: w uroczystość męczeństwa i przeniesienia św. Wojciecha (23 kwietnia i 20 października) i trwały przynajmniej osiem dni. W wieku XVII z powodu napływu spraw, wprowadzono na św. Jana Chrzciciela (24 czerwca) trzecią kapitułę generalną trwającą osiem dni, na której zajmowano się wyłącznie sprawami majątkowymi i gospodarczymi, i stąd nazywano ją kapitułą ekonomiczną. Zob. Korytkowski, Prałaci i kanonicy, t. 1, s. 327. 
nieńskiej: „Jużem się JWW. WM Panom wytłumaczył co do fabryki kościelnej, że ile pozwoli stan majątku mego w tym roku najbardziej kończeniem pałacu w Warszawie ścieśnionego, nie zechcę się wymawiać, żeby miła oblubienica moja prędzej czy później stanęła jednak koniecznie w tej postawie przedsięwziętych ozdób, w jakiej ją chcą mieć układy dojrzałe ukartowane i zgodzone. Rozumiem zaś miłą rzecz donieść JWW. WM Panom, iż gdy suma ich u ś.p. Xięcia Imci Poprzednika mego dekretem ostatecznym teraźniejszego Trybunału postawiona jest za staraniem moim na pewnych i stałych nogach, pisałem do Imć Pana Sędziego Ziemskiego Rawskiego, ażeby na kondescencji w Irżeńsku przypadającej 24 maja tęż summę wraz z przysądzonymi mnie i innym kapitułom, na jednych ziemskich całkowitych dobrach umieścić chciał. Wzięte są na ten koniec przyzwoite środki, które pewność tego skutku niezawodnie obiecują, a tym sposobem łatwiej rzeczone sumy mogą być z czasem od jakiego posesji ziemskiej potrzebnego ochotnika spłaconymi"s3.

W kilkanaście miesięcy później, kiedy pojawiła się możliwość wsparcia finansowego katedry, prymas Ostrowski w czerwcu 1784 roku dwukrotnie polecał, aby na jej odbudowę z arcybiskupiego funduszu (dochodu) przeznaczyć konkretne kwoty. W pierwszym liście z 14 czerwca 1784 roku wyznaczył na ten cel kwotę $1500 \mathrm{złp}^{84}$, natomiast w drugim - z dnia 18 czerwca - $6000 \mathrm{złp:} \mathrm{„Nie} \mathrm{chce}$ wszakże, żeby Fabryka Kościelna osychała. A zatem naznaczone dawniej ode mnie 6000 złotych polskich odciagnąć proszę z rat moich świętojańskich i obrócić na potrzeby tejże fabryki" $"$.

$\mathrm{Na}$ drodze korespondencji, prymas Ostrowski informowany był nie tylko o faktach radosnych, lecz także o ,troskach” i problemach w archidiecezji. Jednym z nich był toczący się spór kanonika Józefa Ryczywolskiego z opatem lędz$\mathrm{kim}^{86}$. Przedmiotem sporu - jak się dowiadujemy z treści listu była sprawa obrony granic Partykularza Szczytnickiego z dóbr konwentu lędzkiego przeznaczonych prymasowi jako opatowi komendatoryjnemu. W tej sprawie abp Ostrowski pisal do kanonika Ryczywolskiego wiosną 1782 roku, jeszcze przed wyjazdem za granicę, dając odpowiednie zalecenia co do postępowania $\mathrm{w}$ sporze $\mathrm{z}$ opatem lędzkim. Przede wszystkim zalecał, aby Ryczywolski nie podejmował zbyt pochopnych decyzji i wstrzymał się do czasu Kapituły Generalnej na św. Wojciecha, podczas której zostaną delegowani prałaci celem zbadania sprawy i porozumieją się z przedstawicielami drugiej strony. Swój list kończył słowami: „Interim upraszam Pana, zostaw rzeczy jak były przed tym, do czasu wyżej wyrażonego" ${ }^{\text {"7 }}$. Do

${ }^{83}$ AAGn, sygn. Listy, nr 2728.

${ }^{84}$ AAGn, sygn. Listy, nr 2734.

${ }^{85}$ AAGn, sygn. Listy, nr 2735.

${ }^{86}$ Według tradycji opatom klasztoru Cystersów w Lądzie przysługiwało prawo zasiadania w stallach i celebrowania przy wielkim ołtarzu katedry gnieźnieńskiej. Jednakże jak pisze Korytkowski, o instalacji któregokolwiek w księgach kapitulnych niegdzie nie ma śladu. Widać, że w aktach kapitulnych instalacji podobnych regularnie nie zapisywano, co pozwala wnioskować, iż opaci o honory w katedrze gnieźnieńskiej nie dbali, zwłaszcza, że one pociągały za sobą opłaty instalacyjne, jak przy rzeczywistych prałatach i kanonikach. Zob. Korytkowski, Prałaci i kanonicy, t. 1, s. 113.

${ }^{87}$ AAGn, sygn. Listy, nr 2718, List datowany w Skierniewicach dnia 9 marca 1782 r. 
sprawy powrócił 21 kwietnia tegoż roku, raz jeszcze przypominając propozycje załatwienia sporu $\mathrm{z}$ opatem lędzkim na drodze ugody ${ }^{88}$. Prawdopodobnie spór toczył się dłużej, skoro w liście z 30 listopada 1782 roku datowanym we Frankfurcie nad Menem metropolita gnieźnieński jeszcze raz apelował, aby go załatwić polubownie ${ }^{89}$. Co więcej, dowiadujemy się nadto, iż sam włączył się w jego zażegnanie, osobiście pisząc do opata lędzkiego, bowiem jak sam stwierdził, nie cierpiał kłótni, zwłaszcza między duchownymi, ,gdzie bez pogorszenia świeckich obyć się nie może" ${ }^{\circ 0}$. Z powyższego przykładu widać, iż abp Ostrowski był człowiekiem, który nie lubił sporów, nieporozumień, zawsze szukającym wspólnego konsensusu, zgody, co licowało z piastowaną przez niego godnością następcy apostołów. Potwierdzeniem tego, jest jeszcze inny list skierowany do kapituły, z 13 stycznia 1784 roku - w którym na wieść o (nieznanym nam bliżej) sporze między opatem wagrowieckim a miastem Wagrowiec prosił, aby nakłonić tego pierwszego do załatwienia sprawy polubownie, ugodowo ${ }^{91}$.

Jak widzimy, podczas pobytu prymasa Ostrowskiego za granica, przedstawione powyżej kwestie stanowiły główne, priorytetowe przedmioty jego zainteresowania w korespondencji z kapitułą metropolitalną w Gnieźnie. Pośród nich było jeszcze wiele innych, drobnych, pojedynczych spraw, które załatwiał drogą korespondencyjną. Wszystkie one świadczą o jego trosce o stan archidiecezji, którą przyszło mu na dłuższy czas opuścić. Wymieńmy niektóre z nich, pojawiające się niekiedy nagle. Któregoś dnia czerwca 1783 roku, nagła nawałnica, która przeszła nad terenem Księstwa Łowickiego, zniszczyła wszystkie stawy rybne w posiadłościach prymasowskich oraz młyny i upusty na rzece Skierniewce ${ }^{92}$. Chcąc zaradzić powstałym szkodom, 8 listopada 1783 roku abp Ostrowski z Frankfurtu napisał do kanonika Ryczywolskiego list, prosząc o zajęcie się zorganizowaniem zarybienia zniszczonych stawów i wydając szczegółowe dyspozycje w tej sprawie $^{93}$.

Niekiedy abp Ostrowski musiał uniżyć się przed kapitułą, prosząc ją o zatwierdzenie wydanych przez niego pewnych przywilejów. W liście z 8 października 1782 roku zwracał się z prośbą o zatwierdzenie przywileju na wójtostwo

${ }^{88}$ AAGn, sygn. Listy, nr 2720, List datowany w Skierniewicach dnia 21 kwietnia $1782 \mathrm{r}$.

${ }^{89}$ AAGn, sygn. Listy, nr 2724: Sprawy z Konwentem Lendzkim tak o granice jako i o mlyn wiadomy, rad bym, ażeby mogły być amicabiliter zaspokojone, a przynajmniej pozostały do powrotu mego. Przyznam się WM Panu, że nie cierpię kłótni, mianowicie między duchownymi, gdzie bez pogorszenia świeckich obyć się nie może. Pisałem od Imć Opata Lendzkiego, proponujac mu zgodę, droga Komplanacyi lub Kompromissu, ale WM Pana bardzo proszę chciej z strony swojej concurrere do tego celu.

${ }^{90}$ Tamże: Pisałem od Imć Opata Lendzkiego, proponujac mu zgodę, droga Komplanacyi lub Kompromissu, ale WM Pana bardzo proszę chciej z strony swojej concurrere do tego celu.

${ }^{91}$ AAGn, sygn. Listy, nr 2733.

${ }^{92}$ AAGn, sygn. Listy, nr 2732: Klęska na stawy moje w Księstwie Łowickim z dużej, nadzwyczajnej in Junio nawatnicy, być musi wiadoma JW. Panu, przez którq utracilem prawie wszystkie ryby, mlyny zaś i upusty (osobliwie na rzece Skierniewskiej) znacznie mam porujnowane, choćby to byty nowe...

${ }^{93}$ Tamże. 
bobrowskie dla niejakiego pana Suskiego ${ }^{94}$. W kilka miesięcy później, tj. w liście z 12 kwietnia 1783 roku kierował do kapituły podobną prośbę: tym razem o zatwierdzenie przywileju na wójtostwo Sierakowice dla niejakiego pana Betche starosty skierniewickiego: „Na ostatek żądam tej powolności po JWW.WM Panach, żebyście przywilej na wójtostwo Sierakowice JP-u Betche staroście skierniewickiemu świeżo wydany approbacją stwierdzić raczyli" ${ }^{95}$. Prałaci i kanonicy gnieźnieńscy obie prośby prymasa - ze zmiennym skutkiem - rozpatrzyli na swej kapitule generalnej w maju 1783 roku, o czym w liście z dnia 9 maja 1783 roku informował ks. kanonik T. Siemieński: „(...) Imć Panu zaś Suskiemu przywilej na wójtostwo w Bobrowie nadany na lat 40 aprobowaliśmy. Na świeże zaś nadania Imć Panu Betche Staroście Skierniewickiemu do wójtostwa Sierakowic przyłączone, ponieważ nigdy wójtostwem nie były, a przeto by alienacją oznaczały, żeśmy zezwolenia naszego nie przyłożyli, będziesz raczył nas mieć JOW. Xca Mość za wymówionych" 96 .

Jeszcze tego samego roku, tj. 4 października 1783 roku (w liście z Frankfurtu) abp Ostrowski upraszał prześwietne gremium prałatów i kanoników, by raczyli zatwierdzić przywilej pozwalający miastu Skierniewice na nabycie gruntów ziemskich pod warunkiem ich uporządkowania ${ }^{97}$.

Abp A.K. Ostrowski przywiązywał dużą wagę do należytego porządku w miastach należących do archidiecezji. Szczególnie dbał o Łowicz i tamtejszą kolegiate - nekropolię prymasów Polski. Dlatego w liście z dnia12 lutego 1783 r. upraszał kapitułę o delegowanie ks. Teodora Siemieńskiego ${ }^{98}$ - dziekana gnieźnieńskiego

${ }^{94}$ AAGn, sygn. Listy, nr 2723: Jednemu z zasłużonych ludzi moich JP Suskiemu pozwolitem okupić Wójtostwo Bobrowskie przez ostatniego donatariusza bardzo opustoszone. Peten zatem jestem mocnej wiary, że stużacy mu na lata przywilej z powodu potrzebnych koniecznie na te podupadtq donatywę nakładów, raczycie JWW.WM Panowie skutecznq swojq utwierdzić approbacjq o którq usilnie do nich zanoszę wstawienie.

${ }^{95}$ AAGn, sygn. Listy, nr 2728

${ }^{96}$ AAGn, ACap. B 677, k. 83.

${ }^{97}$ AAGn, sygn. Listy, nr 2731: Pozwolitem miastu Skierniewicom nabyć pewne grunta pod imieniem lenności chodzace, a w granicach tegoż miasta położone i wydatem na to mój przywilej(....) Spodziewam się, że przywilej $w$ tej osnowie, ile majacy za cel commoditatem et utilitatem publicam, znajdzie u JWW.WM Panów approbację, o którq wielce proszę i obowiqzuję.

${ }^{98}$ Ks. Teodor Siemieński był prałatem gnieźnieńskim, kanonikiem warszawskim i archidiakonem kurzelowskim. Pełnił wiele ważnych urzędów. Między innym w 1778 roku jako delegat kapituły gnieźnieńskiej prezydował dla niej na Trybunale Koronnym. W latach 1780 i 1782 zasiadał jako delegat kapituły metropolitalnej na sejmie walnym warszawskim. Jak pisze J. Korytkowski: $U$ arcybiskupa Ostrowskiego wielkiej doznawat wziętości dla swej zdrowej rady, powagi oraz wielkiej znajomości stosunków kościelnych. Korytkowski, Prałaci i kanonicy, t. 3, Gniezno 1883, s. 483. 
i ks. kanonika Grzegorza Zachariaszewicza ${ }^{99}$ do Komisji Dobrego Porządku ${ }^{100}$ w Łowiczu, w celu zapewnienia jej sprawnego działania ${ }^{101}$. Jak dowiadujemy się z listu, zgodnie z przepisami prawa, w skład KDP wchodzić miała Delegacja Kapitulna, dlatego też prymas poddawał kapitule dwóch kandydatów na jej członków ${ }^{102}$.

Przez wszystkie lata swojej pasterskiej posługi abp Ostrowski nigdy nie zapominał o swoich krewnych oraz oddanych mu sługach. Także przebywając za granicą pamiętał o nich. Przykładem tego jest choćby postać niejakiego kapitana Niezabitowskiego, któremu zaraz po objęciu stolicy w Gnieźnie, ofiarował wójtostwo Strzyżewice. Prawdopodobnie kapituła nie aprobowała tej decyzji i miała co do powyższego wójtostwa inne plany, by nie powiedzieć żądania: przeznaczyć jego fundusz na utrzymanie przy katedrze gnieźnieńskiej kapeli muzykantów. Dowiadujemy się o tym z listu abpa Ostrowskiego z dnia 25 marca 1783 roku: „Odebrałem żądanie JWW.WM Panów w odezwie Ich do mnie de Septima Currentis wyrażone i muszę wyznać, że mnie to wiele kosztuje, iż do myśli ich nie jestem w stanie skutecznie odpowiedzieć. Dawno już na Wójtostwo Strzyżewice w sposobie expektatywy miał mój przywilej JP Kapitan Niezabitowski, a gdy teraz Opatrzność uprzątnęła mu tę donatywę, wziął się zapewne do possesji na mocy służącego sobie prawa. Już z tej strony nie da się obmyślić gotowy i bliski fundusz na trzymanie ustawicznej kapeli przy katedrze. Wszakże mam w ułożeniu zaradzić

${ }^{99}$ Ks. Grzegorz Zachariaszewicz oprócz godności kanonika gnieźnieńskiego był proboszczeminfułatem kamieńskim, opatem komendatoryjnym hebdowskim, kanonikiem inflanckim, łowickim, prepozytem kapituły w Łasku, a od 1809 r. sufraganem łowickim w archidiecezji gnieźnieńskiej. Według oceny J. Korytkowskiego mając wielkie poważanie u króla Stanisława Augusta, a u wszystkich biskupów rzadkie wzięcie, wiele dobrego czynił dla Kościoła i niejedną trudną sprawę doprowadził do pożądanego skutku, czego by kto inny na jego miejscu nie dokonał. J. Korytkowski, Prałaci i kanonicy, t. 4, s. 379. Zob. Nitecki, Biskupi Kościoła w Polsce. s. 232; W. Kwiatkowski, Prymasowska kapituła i kolegiata w Łowiczu (1433-1938), Warszawa 1939, s. 189-190.

${ }^{100}$ AAGn, sygn. Listy, nr 2726. Pierwszą Komisję Dobrego Porządku (tzw. komisję Boni Ordinis) dla Warszawy powołał król Stanisław August Poniatowski w 1765 roku. W trzy lata później, tj. w 1768 roku w celu poprawienia sytuacji miast, sejm postanowił utworzyć komisje porządkowe dla wszystkich większych miastach królewskich. Były to ciała kolegialne, które miały się zajmować porządkowaniem stosunków gospodarczych, finansowych i ludnościowych w miastach. Wydawały one przepisy, głównie cechowe, i zarządzenia usprawniające handel. Dbały o powiększenie dochodów miast oraz ich stan sanitarny, naprawę bruków, mostów, ważniejszych budowli miejskich, wydawały szczegółowe przepisy przeciwpożarowe. Zob. Volumina Legum. Prawa, konstytucje i przywileje Królestwa Polskiego i Wielkiego Księstwa Litewskiego, t. 7, Petersburg 1860, nr 754, s. 351352.

${ }^{101}$ AAGn, sygn. Listy, nr 2726.

102 Tamże: Żeby ustawy Komisji Boni Ordinis w Łowiczu (....) mieć mogty należyta moc, trwatość i powage, i żeby niektóre dawne nadania i zwyczaje do dobrego w tym mieście porzadku przeszkadzajqce, a późniejszymi prawami koronnymi i odmianq czasów, i okoliczności zniszczone, wolno byto tejże Komisji albo z gruntu uchylić, albo nowymi i do dzisiejszego stanu rzeczy przystosowanymi objaśnić układami, a w tym wszystkim prawnie i urzędowanie postępować, potrzebna jest koniecznie ad hunc Actum Delegacja Kapitulna, która gdy JWW.WM. Panowie na tych samych wyżej wspomnianych prałatów wydać zechcecie, zaradzicie tej ważnej potrzebie, i mojemu usilnemu żadaniu które przed nich z ufnościq zanoszę. 
skądinąd tej potrzebie bez kosztu JWW.WM Panów ale zamawiam sobie u nich cierpliwość do powrotu mego" ${ }^{103}$. Jak się później okazało, kapituła nie miała owej cierpliwości w tej sprawie. Prawdopodobnie naciskała prymasa, by zmienił decyzję, co do wydanego przez niego przywileju dla kapitana Niezabitowskiego. Dlatego też w miesiąc później, tj. 22 kwietnia tegoż roku abp Ostrowski raz jeszcze wyjaśniał jej całą sytuację, że Niezabitowski prawnie wszedł w posiadanie powyższego wójtostwa: „Równo prawie z wstępem moim na Stolicę Gnieźnieńską Pan Niezabitowski miał ode mnie obiecane Wójtostwo Strzyżewice, a sama Opatrzność uiściła dla niego tę obietnicę przez zejście ostatniej Possesorki. Uwiadomiony o tym przypadku wydałem stąd Przywilej na tę donatywę wspomnianemu Człowiekowi dobrze mi zasłużonemu, a prawdziwie tego wsparcia potrzebnemu. Uczyniłem tedy co z prawa je miałem moc uczynić a Pan Niezabitowski że się zabrał do posesji za przywilejem moim, nie wiem wcale, w czym popełnił bezprawie. Nie mogę zaś rozumieć, żebyście JWMWM Panowie temu Donatariuszowi aprobacji swojej odmawiać mieli, skoro dotąd tyle ich powolności dla mnie jednostajnie doświadczałem. Ta też jednym jest z najsilniejszych powodów, która mnie pociąga czynić Im z mojej strony wszelkie możne ofiary, i na której, jeżeli pożyję, ani Kościół, JWMWM Panowie szkodować nie będziecie"104. Prawdopodobnie argumentacja prymasa Ostrowskiego przekonała kapitułę, bowiem w liście z dnia 9 maja 1783 roku ks. T. Siemieński w imieniu całego gremium prałatów i kanoników donosił swojemu pasterzowi: „Na przeświadczenie na koniec jak sobie nawet wierne Usługi Sług JOW Xcej Mci Dja poważamy, zostawiliśmy Vigor Septimanali Capitulo, aby po odprawionej Rewizji Wójtostwa Strzyżewic Przywilej na toż Wójtostwo Imci Pu Niezabitowskiemu dany aprobowało" 105. W kilka miesięcy później, tj. 4 października 1783 roku prymas Ostrowski, powrócił raz jeszcze do tej sprawy: „Nikomu nie tajno, dlaczego wójtostwo Strzyżewice nie mogło tak być rozporządzonym, jak JWW.WM Panowie żądaliście. Uczyniłem Im w czasie dokładne przełożenie tej niemożności z mojej strony. A zatem nie chcę tu powtarzać rzeczy już przeszłej a wszystkim jawnej, żebym tą niepotrzebną wzmianką i mnie samego i JWW.WM Panów próżno nie nudził"106.

Zajęcie przez Ostrowskiego powyższego stanowiska w omawianej sprawie nie oznaczało, że nie chciał by istniała kapela przy katedrze. Temat ten podjął w wyżej cytowanym liście z 4 października 1783 roku: „nie rozumiejcie JWW.WM Panowie, żeby interesa najmilszej Oblubienicy mojej Kościoła Metropolitalnego nie tkwiły mi najżywiej w pamięci i uwadze. Jest w ułożeniu moim stałym i nieodmiennym zaradzić o potrzebie kapeli ustawicznej; mam pod ręką środki pewne, dokładne i gotowe, które dopiszą skutecznie temu zamiarowi. (...) A poza tym, gdy da Bóg następującego roku w powrocie do Ojczyzny ku jesieni myślę nieodmiennie obrócić podróż moją na Gniezno, pewien jestem za pomocą Pana Boga ułożyć na ów czas wszystko w sposób najskuteczniejszy ku większej chwale Bo-

${ }^{103}$ AAGn, sygn. Listy, nr 2727.

${ }^{104}$ AAGn, sygn. Listy, nr 2729, (List z dnia 22 kwietnia 1783 r.).

${ }^{105}$ AAGn, ACap. B 677, k. 82v.

${ }^{106}$ AAGn, sygn. Listy, nr 2731. 
skiej i lepszemu służby kościelnej opatrzeniu"107. Z powyższych słów po raz kolejny widać, że cały czas jednym z priorytetów abpa Ostrowskiego w pasterzowaniu w Kościele gnieźnieńskim była troska o archikatedrę - matkę wszystkich kościołów w archidiecezji.

Po kilkumiesięcznym pobycie na leczeniu we Frankfurcie nad Menem, nie widząc jego wpływu na powrót do zdrowia, 30 marca 1783 roku prymas A.K. Ostrowski odnowił swój testament ${ }^{108}$. Jego egzekutorami mianował: ks. Jana Dembowskiego - biskupa koadiutora kamienieckiego, ks. Melchiora Gurowskiego - proboszcza katedry gnieźnieńskiej, oficjała generalnego gnieźnieńskiego, Tomasza Ostrowskiego - kasztelana czerskiego i Ignacego Sucheckiego - chorążego sieradzkiego ${ }^{109}$. W testamencie napisał między innymi: ,Ż̇yłem według rangi, świadczyłem za życia com mógł, komu, z domu mało miałem po rodzicach, łożyłem wiele w biskupstwie Kujawskim, toż czyniłem w Arcybiskupstwie i Księstwie Łowickiem, ale najbardziej oskarżam fatalną na cały kraj rewolucję ostatnią w której równie $\mathrm{z}$ wielu obywatelami nie tylko jakiekolwiek gotowizny, część pretii za sprzedane w Warszawie dwa domy dziedziczne, pałacyk przy ulicy Koziej i kamienicę na Trębackiej, ale też intraty kilkuletnie i przez połowę dóbr w biskupstwie Pomorskim straciłem. Zmniejszono mi też intraty w nowej na prymastostwo intraty już to oderwaniem w kordon cesarki większej połowy opactwa Tynieckiego, już zagarnieniem do Prus Brandenburskich całego klucza Kamińskiego i dwóch prawie części Żnina. Niemało mnie też kosztowały ekspedycje w Rzymie na nowe dostojeństwo, dosyć mnie na starość uciążliwe i życie skracające" ${ }^{110}$. Przytoczony cytat wyraźnie pokazuje, iż na skutek wydarzeń w Rzeczypospolitej po 1772 roku, majątek prymasa Ostrowskiego zubożał, stąd mogła być zrozumiałą niemożność dotowania przez niego w większym wymiarze przebudowy katedry metropolitalnej, na której mu wielce zależało. Nie dziwi więc jego wcześniejsza odmowna odpowiedź kapitule w tej sprawie ${ }^{111}$.

Testament swój abp Ostrowski kończył słowami: „Gdy stanę przed najwyższym wielkiego Boga majestatem i zdawać będę rachunek spraw moich z powierzonego w Kościele i Senacie urzędu pierwszego, nie spodziewam się być strofowanym, gdy jako Metropolita w Narodzie Polskim zaświadczę politycznym testamentem niepochlebnie ani obojętnie, że Król Jegomość, Pan nasz Miłościwy właściwe ojcowskie serce mając dla całej Nacji, nigdy nie pokazał się w tych dyspozycjach, aby za jego panowania najmniejsze uszczuplenie kraju albo prerogatyw obywatelskich nastapiło. Wiedziałem po części intencje tego dobrego Pana; czynił, co mógł, na wprowadzenie rządu lepszego, na konsyderacją większą

107 Tamże.

${ }^{108}$ AAGn, ACap. B38, k.425-432.

109 Tamże, k. 425; Korytkowski, Prymasi Polski, s. 78.

${ }^{110}$ AAGn, ACap. B38, k. 427.

111 Według testamentu pozostało w spadku po osobistym majątku po prymasie ok. 970.000 złotych, które w większości zapisał swoim krewnym. Z pozostałej sumy ok. 300.000 złotych przeznaczył na koszty pogrzebu, szpital Dzieciątka Jezus w Warszawie, szpitale przy kościele farnym w Skierniewicach, katedrę gnieźnieńską, kolegiatę w Łowiczu i kościół farny w Skierniewicach. Zob. AAGn, ACap. B38, k.427-431. 
Królestwa i Państwa swego, aleśmy nie wszyscy chcieli pójść torem rady i perswazji, a przeto zbłądziliśmy, a daj Boże, ażebyśmy kiedykolwiek postrzec się mogli. Oskarżać należy dawniejsze omissy, które nas w obiekcję wprawiły; narzekać na niesforność naszą i emulacje z prywatnych przyczyn pochodzące; poprawić się w gorliwości ku Ojczyźnie ścieśnionej wielu fatalnymi przypadkami; nie żałować choć już reszty majątku na postawienie się w lepszej sytuacji, myśleć sistematice, kochać króla, mieć w nim ufność. Te są ostatnie wota obywatelskie końcem wypłacenia się wdzięcznością Ojczyźnie, na której łonie chowałem się i za której powodzenie szczęśliwe modlić się będę w translacji mojej na świat drugi, aby Bóg wszechmogący natchnął pozostałych ziomków moich do zachowania Religii świętej, wolności użytecznej, ut sua bona vellint et ut sua mala nollint. Takowy testament przy zdrowym zmyśle z należytą refleksją i deliberacją czyniony, własną ręką moją pisany, tąż podpisuję i pieczęcią moją stwierdzam" "112. Ze słów tych wypływa spokój Ostrowskiego, gdy chodzi o ocenę pełnionego przez siebie urzędu, choć zauważył tutaj pewne własne niedomagania i braki.

W oparciu o przytoczone fragmenty korespondencji, widzimy, że przez cały czas pobytu za granicą prymas Ostrowski gorliwie zajmował się sprawami archidiecezji i był w stałym kontakcie z kapitułą gnieźnieńską i poszczególnymi jej członkami.

Biorąc pod uwagę całą działalność prymasa, wydaje się, że abp Ostrowski niesłusznie został potraktowany przez historyków jako człowiek dbający tylko i wyłącznie o własne dochody. Był biskupem, który może znienawidzony przez nuncjusza abpa Angelo Duriniego ${ }^{113}$, jako uległy dworowi króla Stanisława Augusta Poniatowskiego, a potem Rosji, oraz mający spryt do interesów, jednak pamiętał i dbał najpierw o powierzone mu diecezje inflancką i włocławską a potem archidiecezję gnieźnieńską nie gorzej od innych współczesnych mu rządców diecezji polskich. Interweniował we wszystkie objawy jej życia z poczuciem odpowiedzialności za powierzoną mu kościelną placówkę administracyjno-duszpasterską.

Należy jednak przyznać, iż niestety abp Ostrowski nie był człowiekiem bez skazy. Zarzuca mu się zbyt frywolny, by nie powiedzieć hulaszczy tryb życia i to nawet do końca jego dni ${ }^{114}$. Współczesny Ostrowskiemu poeta Józef Bielawski, który w tym czasie, co prymas, bawił w Paryżu, tak opisał życie paryskie dworu prymasowskiego: „,zeladka jego (...) według porządku Kościoła osusza piwnice swoją facjatą, a godny prałat ksiądz Nowicki wyciera z Życiem (Życzyńskim) kąty poświęcone nocnej tylko swawoli i rozpuście; tego gatunku bydło trzeba było posłać albo do Betleem dla wymeblowania stajenki Nowonarodzonemu, albo przepędziwszy do Paryża nie pokazywać tylko za pieniądze" ${ }^{115}$. Fakt ten na

${ }^{112}$ Tamże, k. 432.

${ }^{113}$ Abp Angelo Maria Durini urząd nuncjusza Stolicy Apostolskiej w Rzeczypospolitej pełnił od 1767 do 1772 roku, kiedy to pod naciskiem Katarzyny II i króla Stanisława Augusta Poniatowskiego został zmuszony do opuszczenia Polski.

${ }^{114}$ Wspomnieliśmy już wcześniej o utrzymywanym przez prymasa „fraucymerze” w Warszawie i tzw. ,prymasarni" w Skierniewicach.

${ }^{115}$ K. M. Morawski, Ignacy Potocki, cz. 1 (1750-1788), Warszawa 1911, s. 55. 
pewno nie wpływa korzystnie na całościowy osąd o arcybiskupie Antonim Kazimierzu Ostrowskim.

W niniejszym artykule staraliśmy się ukazać, na ile w czasie swego dwuletniego pobytu za granicą prymas Ostrowski interesował się sprawami archidiecezji gnieźnieńskiej. Z zacytowanej korespondencji jasno wynika, że do ostatnich chwil swego życia - pomimo różnych ,słabości” - pozostając w stałym kontakcie z kapitułą metropolitalna, chciał być informowany o wszystkim, co ważnego dzieje się w jego „owczarni”, a w ważnych sprawach samemu podejmował decyzje.

Chcąc podjąć próbę oceny jego osoby, można nieśmiało powiedzieć, iż jako pasterz troszczył się swoją archidiecezję, nie zawsze świecąc własnym przykładem, natomiast jako senator-polityk i mąż stanu pozostawił po sobie smutną pamięć, wykazując się chwiejnością, uległością i bojaźnią wobec Rosji. Jak pisze o nim J. Korytkowski: „Nie zła wola i obojętność ku losom Rzeczypospolitej, bo przywiązania ku niej rozliczne dał dowody, ale raczej brak zdolności politycznych i krótko widzenie były powodem niedołężności i słabości w chwilach stanowczych"116. Ostatecznym jednak sprawiedliwym jego sędzią jest Bóg.

\title{
A PRIMATE OF POLAND - ARCHBISHOP ANTONI KAZIMIERZ OSTROWSKI'S CARE OF HIS ARCHDIOCESE, DURING HIS STAY ABROAD, IN THE LIGHT OF HIS CORRESPONDENCES WITH THE METROPOLITAN CHAPTER OF GNIEZO
}

\begin{abstract}
Summary
Archbishop Antoni Kazimierz Ostrowski was the primate of Poland in the years 17771784. In older historiography Ostrowski was praised for his deep inner life, ascetical practices, exemplary life, works of mercy, approachability and hospitality. However, some new investigations put in doubt his exemplary priestly conduct. Primate Ostrowski who was sick then spent last two years of his life (1782-1784) abroad where he underwent medical treatment. We have a large correspondence from this period between the primate and the cathedral chapter of Gniezno. The author of the article analyzes these correspondences and clearly shows that archbishop Ostrowski, even when abroad, he really cared for his archdiocese's affairs. Among his particular interest were the construction of a new seminary building, the renovation of the metropolitan cathedral of Gniezno and the expanding of the Primate's palace in Warsaw. The article wants to prove that - despite numerous opinions about the Primate's weaknesses - till the end of his life he strove to be a good shepherd, doing a lot of good things for his archdiocese and for the Church.
\end{abstract}

${ }^{116}$ Korytkowski, Prymasi Polski, s. 110. 